\title{
RESIDIVIS DALAM PERSPEKTIF SOSIOLOGI HUKUM
}

\author{
La Patuju \\ Sakticakra Salimin Afamery \\ Fakultas Hukum Universitas Halu Oleo Kendari \\ Dosen Hukum Tata Negara \\ E-mail:lapatuju@gmail.com \\ E-mail: sakti.cakra15@gmail.com
}

\begin{abstract}
ABSTRAK.
Munculnya kelompok residivis atau kejahatan yang dilakukan secara berulang-ulang merupakan bukti lemahnya penerapan sistem hukum khususnya pada aspek pemberian sanksi. Pemberian sanksi selama ini hanya sekedar memberikan rasa malu, namun tidak memberikan efek jera kepada pelanggar hukum. Dalam perspektif sosiologi hukum, jika kondisi ini tetap dipertahankan akan muncul patologi sosial dalam masyarakat yakni kelompok yang melakukan pelanggaran hukum namun sudah tidak memiliki rasa malu atau dikenal dengan istilah residivis. Kondisi ini bukan berarti sudah tidak dapat dicegah, akan tetapi semuanya akan dapat diatasi jikalau semua pihak mulai dari aparat penegak hukum, praktisi, pemerintah, dan masyarakat mau mempertemukan persepsi untuk bekerjasama dalam rangka memberantas penyakit sosial ini. Cukup dengan menciptakan sebuah sistem hukum yang membuat nyaman dan dibutuhkan oleh masyarakat, maka sistem itu akan berjalan efektif.
\end{abstract}

Kata Kunci:Residivis, Perspektif dan Sosiologi Hukum

\begin{abstract}
The emergence of groups of recidivists or crimes committed repeatedly is evidence of weak implementation of the legal system, especially in the aspect of sanctions. Sanctions for this just gives a shame, but it does not provide a deterrent effect to offenders. In the perspective of sociology of law, if this condition is maintained will appear social pathology in a society that is the group that have violated the law, but they have no shame or known as recidivists. This condition does not mean that is not preventable, but everything will be overcome if all parties including law enforcement agencies, practitioners, government, and the people need to reconcile the perception to cooperate in order to eradicate this social disease. Simply by creating a legal system that makes it convenient and needed by the community, then the system would operate effectively.
\end{abstract}

Keywords: Recidivists, Perspectives and Sociology of Law 


\section{A. PENDAHULUAN}

Masyarakat dan ketertibannya merupakan dua hal yang berhubungan sangat erat, bahkan bisa juga dikatakan sebagai dua sisi dari satu mata uang. Susah untuk mengatakan adanya masyarakat tanpa ada suatu ketertiban, bagaimanapun kualitasnya (Rahardjo,2000). Kehidupan dalam masyarakat yang sedikit banyak berjalan dengan tertib dan teratur ini tentu didukung oleh suatu tatanan yang dinamakan norma hukum.

Norma hukum disebut juga dengan norma tingkah laku. Hukum merumuskan perbuatan-perbuatan yang diperintahkan untuk dilakukan dalam bentuk yang umum, sehingga dengan satu norma saja bisa mencakup banyak macam perbuatan di dalamnya (Rahardjo, 2000). Dalam perspektif inilah yang kemudian hukum dapat dikatakan berjalan efektif jika terdapat potensi untuk mengatur peristiwa hukum.

Dalam perkembangan hukum di Indonesia, terdapat beberapa ketimpangan serta peristiwa-peristiwa hukum lainnya yang sudah mencapai angka yang relatif tinggi. Yang mejadikan hal itu terjadi, salah satunya adalah lemahnya pemberian sanksi atau hukuman bagi pelanggar hukum. Pemberian sanksi terhadap pelanggar hukum di Indonesia hanya bersifat memberikan rasa "malu", bukan memberikan efek "jera”. Para penegak hukum dengan antusiasnya memamerkan pasal-pasal yang berjejaljejal dalam pengadilan untuk menjerat pelaku pelanggaran hukum namun hasil yang didapatkan hanya keberhasilan semu, karena mereka tidak didukung dengan sistem pemberian sanksi yang menimbulkan efek jera.

Pertanyaan yang muncul kemudian adalah bagaimana dengan pelanggar hukum yang sudah hilang rasa malunya, apakah sanksi yang berupa hukuman kurungan dapat membuat mereka jera ? Itulah yang menjadi masalah krusial dalam aspek hukum yang melanda bangsa ini. Akibat dari masalah ini adalah munculnya patologi sosial atau penyakit masyarakat yang melahirkan beberapa oknum tertentu yang kesibukannya hanya sebatas "kelaur masuk bui".

Patologi sosial yang dimaksud adalah munculnya kelompok residivis. Residivis adalah istilah dalam hukum untuk jenis kejahatan yang tidak dapat 
dihentikan akan tetapi hanya dapat dicegah. Ibarat jenis penyakit yang tidak dapat diobati dan hanya dapat dicegah. Dalam Kamus Bahasa Indonesia (2008), istilah residivis diartikan sebagai orang yang pernah dihukum mengulangi tindak kejahatan yang serupa atau biasa disebut penjahat kambuhan. Dengan demikian, menjadi penting bagi penulis untuk menelaah secara kritis seputar pandangan sosiologi hukum mengenai fenomena residivis yang melanda bangsa dewasa ini.

\section{B. METODE PENELITIAN}

Terdapat berbagai pendekatan dalam ilmu sosial dan yang digunakan dalam tulisan ini adalah pendekatan fenomenologi, untuk melihat dan memahami fenonema sosial yang terjadi di masyarakat. Nindito (2005) mengungkapkan bahwa ide dasar dari fenomenologi Schutz bukan sebagai suatu teori atau pendekatan, tetapi merupakan bentuk gerakan yang bersifat filosofis di abad 20-an yang menjadikan ilmu sosial termasuk dalam ilmu humaniora. Dalam artian bahwa, aktor sosial menjalankan peran simultan untuk membangun makna dan memberikan nilai dalam setiap interaksi. Dengan demikian, fenomena residivis dikaji dari perspektif sosiologi hukum melalui pendekatan fenomenologi untuk menghasilkan kajian kritis dan reflektif.

Telaah yang terdapat di dalamnya merupakan deskripsi fenomenologis yang menggambarkan peristiwa hukum yang berkaitan dengan residivis dan berbagai problematikanya di masyarakat. Hal ini didapatkan dari diskusi langung maupun tak langsung yang diperoleh dari oknum pelaku dan pihak-pihak yang mengetahui seluk beluk mengenai residivis. Fenomena tersebut kemudian didekati dan dikaji dari perspektif sosiologi hukum.

\section{KERANGKA TEORI}

\section{Konsep Residivis}

Pengertian residivis menurut pendapat para ahli hukum pidana, seperti; (1) Yonkers, bahwa residivis itu merupakan alasan untuk memperberat hukuman dan bisa juga memperingan hukuman; (2) Hazenwinkel dan Pompe, dengan alasan serupa dengan Yongkers, bahwa residivis sebagai alasan memperberat dan meringankan hukuman; (3) Vos berpendapat bahwa residivis adalah sebagai alasan untuk memperberat hukuman; (4) Utrecht berpendapat bahwa residivis sama 
dengan gabungan yang dijadikan sebagai dasar pertimbangan untuk memperberat hukuman; (5) Soesilo juga berpendapat yang sama dengan Utrecht mengenai residivis yaitu residivis sama dengan gabungan yang dijelaskan dalam Pasal 486 sampai dengan 488 KUHP (Ngani, 1984).

Berdasarkan beberapa pendapat para ahli tersebut dapat disimpulkan bahwa residivis merupakan alasan pemberatan hukuman dan residivis bisa digolongkan ke dalam gabungan. Pompe berpendapat bahwa persamaan antara residivis dengan gabungan ialah bahwa pelaku perbuatan tersebut telah berturut-turut melakukan perbuatan pidana. Sedangkan perbedaannya adalah bahwa kalau dalam gabungan antara perbuatan yang satu dengan yang lainnya belum pernah ada vonis hakim. Sedangkan Vos berpendapat bahwa persamaan antara keduanya ialah (dengan lebih menitik beratkan samenloop/concurcus realis) bahwa satu orang telah melakukan beberapa peristiwa pidana. Sedangkan perbedaannnya ialah bahwa dalam soal residivis, diantara peristiwa-peristiwa pidana yang dilakukan itu sudah ditetapkan suatu hukuman/vonis hakim (Ngani, 1984).

Dalam istilah hukum positif pengertian pengulangan tindak pidana (residivis) adalah dikerjakannya suatu tindak pidana oleh seseorang sesudah ia melakukan tindak pidana lain yang telah mendapat keputusan akhir (Suerodibroto, 2004). Artinya, pemberatan pidana terhadap residivis dapat berlaku apabila ia telah mendapatkan keputusan hukum yang tetap atas perbuatan yang sama.

Adapun sebab-sebab terjadinya pemberatan pidana (Abidin, 2007) adalah sebagai berikut:

1. Pelakunya adalah orang yang sama;

2. Terulangnya tindak pidana dan untuk tindak pidana terdahulu telah dijatuhi pidana oleh suatu keputusan hakim;

3. Si pelaku sudah pernah menjalani hukuman atau hukuman penjara yang dijatuhkan terhadapnya;

4. Pengulangan terjadi dalam waktu tertentu.

Jadi tidak sembarang perbuatan pidana seseorang bisa dikatakan sebagai 
residivis, karena ada kriteria atau ketentuan-ketentuan yang telah diatur atau ditetapkan, sehingga perbuatan pidana bisa dikatakan sebagai residivis. Berdasarkan pengertian recidivis di atas merupakan sama dengan pengulangan tindak pidana yang dilakukan oleh seseorang yang telah pernah dipidana. Hampir sama dengan ajaran perbarengan/gabungan dalam melakukan tindak pidana, akan tetapi di antara keduanya ada perbedaannya.

Di dalam Kitab Undang-Undang Hukum Pidana (KUHP) ada 2 (dua) macam residivis (Sumidjo, 1985), yaitu:

1. Residivis Umum (general recidive), maksudnya tidak diperhatikan sifat perbuatan pidana yang diulangi, artinya asal saja residivis mengulangi perbuatan pidana, meskipun perbuatan tersebut tidak sejenis dengan perbuatan pidana terdahulu akan tetapi tetap digolongkan sebagai pengulangan. Residivis umum diatur dalam pasal 486 sampai dengan pasal 488 KUHP.

2. Residivis Khusus (special residive), maksudnya sifat dari pada perbuatan pidana yang diulangi sangat diperhatikan, artinya perbuatan yang diulangi harus semacam atau segolongan dengan perbuatan pidana terdahulu, atas perbuatan apa yang bersangkutan pernah menjalani hukuman. Menurut ajaran residivis khusus, maka setiap pasal KUHP mempunyai ajaran peraturan tentang resdivis tersendiri, seperti dalam pasal 489 ayat (2), pasal 495 ayat (2), pasal 512 ayat (3) dan seterusnya.

\section{Perspektif Sosiologi Hukum}

Sosiologi hukum memadukan dua istilah yang awalnya digunakan secara terpisah, yakni sosiologi dan hukum. Secara terminologis yang dimaksudkan dengan hukum disini bukan ilmu hukum, melainkan berbagai bentuk kaidah sosial atau norma, etika berperilaku, peraturan, undang-undang, kebijakan, dan sebagainya yang berfungsi mengatur kehidupan manusia dalam bermasyarakat, bertindak untuk dirinya atau orang lain, dan perilaku atau tingkah pola lainnya yang berhubungan dengan kehidupan berbangsa dan bernegara. Dengan demikian, sosiologi hukum lebih tepat merupakan kajian ilmu sosial terhadap hukum yang berlaku di masyarakat dan 
perilaku serta gejala sosial yang menjadi penyebab lahirnya hukum di masyarakat. Kehadirannya dapat didahului oleh hukum dan sebaliknya oleh masyarakat, yang secara substansial gejala sosial menjadi bagian penting dari gejala hukum di masyarakat, sebagaimana gejala hukum merupakan gejala sosial (Ahmad Saebani, 2007).

Sosiologi hukum senantiasa menguji kesahihan empiris (emprical validity) dari suatu peraturan atau pernyataan hukum. Pertanyaan yang bersifat khas di sini adalah "Bagaimanakah dalam kenyataannya peraturan itu ?", "apakah kenyataan memang seperti tertera pada bunyi peraturan ?"Perbedaan yang besar antara pendekatan tradisional yang normatif dan pendekatan sosiologis adalah bahwa yang pertama menerima saja apa yang tertera pada peraturan hukum, sedang yang kedua senantiasa mengujinya dengan data empiris (Rahardjo, 2000).

Sosiologi hukum tidak melakukan penilaian terhadap hukum. Tingkah laku yang mentaati hukum dan yang menyimpang dari hukum sama-sama merupakan objek pengamatan yang setara. Ia tidak menilai yang satu lebih dari yang lain. Perhatiannya yang utama hanyalah pada memberikan penjelasan tehadap objek yang dipelajarinya. Pendekatan yang demikian itu sering menimbulkan salah paham, seolah-olah sosiologi hukum ingin membenarkan praktek-praktek yang menyimpang atau melanggar hukum. Sekali lagi dikemukakan di sini bahwa sosiologi hukum tidak memberikan penilaian, melainkan mendekati hukum dari segi objektifitas semata dan bertujuan untuk memberikan penjelasan terhadap fenomena hukum yang nyata, termasuk fenomena kejahatan yang berulangulang dalam hal ini residivis.

\section{PEMBAHASAN HASIL PENELITIAN DAN ANALISIS}

Dewasa ini, istilah residivis sudah tidak asing lagi bagi masyarakat Indonesia secara umum, bahkan sudah dikenal istilah residivis bandar Narkoba, residivis pencurian kendaraan bermotor (curanmor) dan jenis residivis lainnya. Bagi pelaku kejahatan ini, mereka tidak merasa malu dengan apa yang mereka 
telah lakukan karena memang mereka tahu bahwa meskipun mereka dijerat hukum, hanya akan mendapatkan hukuman kurungan dalam beberapa waktu kemudian keluar lagi. Kondisi ini diperparah dengan kenyataan bahwa mereka sudah tidak lagi memiliki rasa malu dengan apa yang mereka yang lakukan karena mereka pun tahu sanksi yang diberikan tidak menimbulkan efek jera bagi mereka. Jika seperti ini keadaannya, maka merupakan hal yang wajar jika mereka kemudian punya kesibukan hanya sebatas "keluar masuk penjara/bui".

Seperti diketahui bahwa semua tindak kejahatan yang dilakukan oleh warga negara akan menjalani yang namanya proses hukum, tidak terkecuali bagi residivis. Semuanya mendapatkan perlakuan yang sama untuk menjunjung tinggi supremasi hukum. Seperti misalnya bagi kelompok residivis yang akrab dengan aksi pencurian yang tentu saja merugikan bagi korban. Akan tetapi, dalam prakteknya tidak jarang ditemukan para tersangka residivis pencurian tidak mendapatkan hukuman yang pantas mereka dapatkan sesuai dengan yang disebutkan dalam Pasal 362-367 KUHP yang mengatur mengenai Pencurian ataupun Pasal 486 KUHP yang mengatur mengenai ancaman maksimal pidana terhadap residivis yang melakukan kejahatan harta benda khususnya pencurian.

Keadaan tersebut menunjukkan adanya kontradiksi antara amanat Pasal-Pasal KUHP tentang residivis dengan kenyataan yang didapatkan oleh para residivis. Dalam kasus seperti ini biasanya disebabkan oleh Hakim yang menangani kasus tesebut, bukan berarti hakim yang bertanggung jawab atas carut marutnya persoalan hukum di negeri ini. Misalnya dalam kasus pencurian, Hakim dalam mengambil keputusan tentunya mempunyai beberapa pertimbangan khusus, seperti misalnya dalam menjatuhkan putusan pidananya, hakim memiliki suatu asas yaitu asas independency ofjudiciaiy.

Oleh karena pertimbangan hakim dalam menjatuhkan putusan pidana itu melalui suatu proses yang panjang, perlu diketahui faktor-faktor apakah yang melandasi hakim dalam menjatuhkan putusan pidana terhadap residivis yang melakukan pencurian dan dasar hukum yang melandasi hakim dalam menjatuhkan putusan pidana 
terhadap residivis. Pertimbangan hakim dalam menjatuhkan putusan pidana terhadap residivis tersebut dipengaruhi oleh unsur-unsur rnengenai pasal pencurian yang dilanggar dan Pasal 486 KUHP tentang residivis, faktor psikologis-sosiologis residivis dan faktor pertimbangan di luar KUHP yang terdiri dari serius atau tidaknya modus operandi yang dilakukan, jumlah kerugian yang diderita oleh si korban, dan hal-hal yang dapat memperberat dan meringankan hukuman residivis atau dengan perkataan lain erat kaitannya dengan faktor subyektif hakim.

\section{Kondisi}

tersebut

menggambarkan sebuah keadaan dilematis yang tentunya lebih dirasakan oleh hakim yang menangani kasus demikian. Hakim berusaha menjunjung tinggi nilai-nilai keadilan baik bagi pelaku maupun korban. Sebuah kondisi yang kemudian diperparah bahwa ternyata sanksi yang dijatuhkan pun tidak memberikan efek jera terhadap residivis. Sungguh sangat mubazir atau sia-sia ketika semua penegak hukum berupaya menjerat si residivis, jika pada akhirnya pelaku tersebut sudah tidak memiliki rasa malu. Tak pelak lagi keadaan seperti ini terjawab sebagaimana yang dimaksud oleh Emile Durkheim dalam paradigma fakta sosial dan Max Weber dengan paradigma defenisi sosialnya (Ritzer, 1996).

Paradigma fakta sosial berasumsi bahwa masyarakatlah yang menentukan individu sedangkan dalam paradigma defenisi sosial menyatakan bahwa individulah yang menentukan masyarakat. Seperti itulah keadaan antara kelompok residivis dengan posisi para penegak hukum. Yang menyebabkan seorang individu masuk dalam kelompok residivis karena sistem peradilan hukum yang memang belum memberikan efek jera, maksudnya adalah residivis berbuat pelanggaran hukum karena seolah-olah sistem mengizinkan untuk berbuat hal demikian karena sanksinya yang tidak tegas. Dalam hal ini sistem tersebut mempengaruhi individu dalam masyarakat seperti yang dimaksud oleh paradigma fakta sosial.

Tak hanya itu, kondisi masyarakat kontemporer sebagaimana yang dimaksud oleh Piliang (1998) bahwa hilangnya rasa malu di dalam diri kita, di dalam masyarakat kita, serta di seluruh aspek kehidupan kita, semakin 
memperkuat potensi masyarakat untuk melakukan tindak kejahatan secara berulang-ulang. Apalah arti sebuah aturan jika pada akhirnya tidak begitu diindahkan oleh manusia kontemporer yang katanya sudah tidak memiliki rasa malu itu.

Menerapkan hukum terhadap masyarakat yang tidak memiliki rasa malu, tentu merupakan sebuah kenyataan yang lucu. Akan tetapi, ikhwal inilah yang yang menghambat jalannya proses pembangunan hukum dan pembangunan nasional secara umum di bangsa kita. Sudah saatnya bagi siapa saja yang concern di bidang pembangunan hukum untuk merekonstruksi bangunan hukum yang pada gilirannya akan melahirkan ketaatan hukum pada masyarakat, bukan sebaliknya.

Dalam setiap usaha untuk merealisasikan tujuan pembangunan, maka sistem hukum itu dapat memainkan peranan sebagai pendukung dan penunjangnya. Suatu sistem hukum yang tidak efektif tentunya akan menghambat terealisasinya tujuan yang ingin dicapai itu. Sistem hukum dapat dikatakan efektif bila perilaku-perilaku manusia di dalam masyarakat sesuai dengan apa yang telah ditentukan di dalam aturan-atruan hukum yang berlaku. Paul dan Diaz (dalam Warassih, 2011) mengajukan lima syarat yang harus dipenuhi untuk mengefektifkan sistem hukum itu yakni:

a) Mudah tidaknya makna aturanaturan hukum itu untuk ditangkap dan dipahami;

b) Luas tidaknya kalangan di dalam masyarakat yang mengetahui isi aturan-atruan hukum yang bersangkutan;

c) Efisisen dan efektif tidaknya mobilisasi aturan-aturan;

d) Adanya mekanisme penyelesaian sengketa yang tidak hanya mudah dijangkau dan dimasuki oleh setiap warga masyarakat, melainkan juga harus cukup efektif dalam neyelesaikan sengketa-sengketa;

e) Adanya anggapan dan pengakuan yang merata di kalangan warga masyarakat bahwa aturan-aturan dan pranata-pranata hukum itu memang sesungguhnya berdaya kemampuan yang efektif.

Lima syarat itu diperlukan untuk melegitimasi keberlakuan hukum serta diterimanya hukum itu oleh masyarakat. Jika seandainya kelompok residivis menganggap hukum itu sebagai 
kebutuhan mereka, maka sudah pasti tindakan mereka tersebut tidak akan terjadi. Namun karena bagi mereka hukum itu seolah hanya bahan permainan saja, wajarlah jika pada akhirnya aktifitas keluar masuk bui menjadi rutinitas mereka. Bukankah tindakan residivs ini merupakan bentuk pelecehan terhadap hukum itu sendiri ? Olehnya itu, jika saja pemberian sanksi kepada kelompok residivis ini mampu memberikan efek jera, maka dapat dipastikan perbuatan mereka tidak akan terulang kembali.

\section{E. PENUTUP}

Di tengah carut marutnya sistem penegakkan hukum di bangsa ini, bukan berarti jalan untuk menciptakan sistem hukum yang ideal di masyarakat akan terhambat. Begitu pula dengan efektifitas penerapan sanksi yang sebenarnya cukup dengan menemukan sebuah formulasi yang masyarakat merasa nyaman dan membutuhkan hukum itu. Jika usaha ini dapat ditempuh, maka pada gilirannya akan menjadikan semua model pemeberian sanksi terhadap pelanggar hukum, berjalan efektif termasuk kepada kelompok residivis.
Usaha tersebut dapat ditempuh melalui kerjasama atau kombinasi peran semua stakeholder pembangunan hukum. Kalangan praktisi, pemerintah, dan masyarakat perlu mempertemukan pandangan agar kemudian setiap gejala sosial yang timbul di masyarakat dapat dicegah sedini mungkin. Sebagai akhir dari tulisan ini, perlu kiranya kita merenungi kembali apa yang pernah disampaikan oleh Max Weber bahwa" Orang tak akan mungkin berhasil mencapai sesuatu yang mungkin dicapai, kecuali apabila dia tanpa putusputusnya berani mencoba menjangkau hal-hal yang tampaknya tak mungkin dicapai"

\section{DAFTAR PUSTAKA}

Abidin, Zainal. 2007. Hukum Pidana I. Sinar Grafika. Jakarta.

Ahmad Saebani, Beni. 2007. Sosiologi Hukum.: Pustaka Setia. Bandung Kamus Bahasa Indonesia, 2008. Pusat Bahasa Departemen Pendidikan Nasional. Jakarta.

Ngani, Nico. 1984. Sinerama Hukum Pidana Asas, Acara, Pidana I, Pidana II).Liberty Yogyakarta.

Nindito, Stefanus. 2005. Fenomenologi Alfred Schutz: Studi Tentang Konstruksi Makna dan Realitas 
dalam Ilmu Sosial. Jurnal Ilmu

Komunikasi, Volume 2, Nomor 1,

Juni 2005.

Piliang, Amir, Yasraf. 1998. Sebuah

Dunia Yang Dilipat, Realitas

Kebudayaan Menjelang Milenium

Ketiga dan Matinya

Postmodernisme. Mizan.

Bandung.

Rahardjo, Satjipto. 2000. Ilmu

Hukum.Citra Aditya Bakti.

Bandung.

Ritzer, George, 1996. Sosiologi, Ilmu

Pengetahuan Berparadigma

Ganda, Penerjemah:

Alimandan.Rajawali. Jakarta.

Suerodibroto, Soenarto. R. 2004. KUHP

dan KUHAP. Raja Grafindo.

Jakarta

Sumidjo, 1985. Pengantar Hukum

Indonesia. Armoco. Bandung

Warassih, Esmi. 2011. Pranata Hukum,

Sebuah Telaah Sosiologis.Badan

Penerbit Universitas Diponegoro.

Semarang. 